\title{
New data on the stratigraphic distribution of the nannofossil genus Catinaster and on evolutionary relationships among its species
}

\author{
MARINA CIUMMELLI* \& ISABELLA RAFFI \\ Dipartimento di Ingegneria e Geologia (Ingeo) - CeRSGeo, Università 'G. d'Annunzio' di Chieti-Pescara, Chieti Scalo, Italy \\ *Corresponding author (e-mail: m.ciummelli@unich.it)
}

\begin{abstract}
Examination of Upper Miocene-Lower Pliocene sediments at IODP Site U1338, in the Eastern Equatorial Pacific, provided new data on the distribution range of the calcareous nannofossil genus Catinaster. In addition to the the well-known occurrence of Catinaster coalitus and Catinaster calyculus in the early Late Miocene, we document Catinaster mexicanus in both the mid-late Miocene and the Early Pliocene. We confirm its taxonomic validity, rejecting previous interpretations of Pliocene C. mexicanus specimens as the result of dissolution of Discoaster altus. Instead, the Pliocene appearance of C. mexicanus seems to originate from the $D$. altus lineage. The short interval of occurrence $(c .50 \mathrm{ka})$ in the Late Miocene may document a preliminary evolutionary emergence of $C$. mexicanus that lacks any relationship with the other Catinaster species. Clear ancestor species to validate its independent origin from Discoaster are, however, missing. In the stratigraphic intervals where Catinaster species are found, their co-occurrence with Discoaster species bearing a prominent star-shaped boss on one side is noteworthy. This suggests that Catinaster and Discoaster at times developed a common morphological feature (a stellate structure, with or without hexaradiate symmetry), possibly under recurrent changes in climatic/environmental conditions. The data presented on C. mexicanus suggest a wider geographical distribution than previously thought, extending from the tropical Pacific to the Gulf of Mexico, equatorial Atlantic and tropical Indian oceans. J. Micropalaeontol. 32(2): 197-205, July 2013.
\end{abstract}

KEYWORDS: calcareous nannofossils, Catinaster, Upper Miocene-Lower Pliocne, distribution range

\section{INTRODUCTION}

During a biostratigraphic study of Upper Miocene-Lower Pliocene sediment cores from IODP Site U1338 (Pälike et al., 2010; Backman et al., 2013), located in the Eastern Equatorial Pacific (Fig. 1), discontinuous occurrences of specimens belonging to the genus Catinaster were observed. This observation prompted investigation in more detail of the stratigraphic distribution of Catinaster. This genus comprises rather small (5$10 \mu \mathrm{m}$ ) forms taxonomically related to Discoaster, and both genera belong to the family Discoasteraceae (Tan, 1927), informally referred to as 'discoasterids'. Two well-established species, Catinaster coalitus Martini \& Bramlette, 1963 and C. calyculus Martini \& Bramlette, 1963, characterize the calcareous nannofossil assemblages in deep-sea sediments during a $c$. 1 Ma time interval in the Late Miocene (from $10.79 \mathrm{Ma}$ to $9.65 \mathrm{Ma}$; Backman et al., 2012). Another species, Catinaster mexicanus, has been observed sporadically at various locations (Fig. 1) from different stratigraphic intervals. It was described by Bukry (1971) from Upper Miocene sediments (c. $8 \mathrm{Ma}$ in age) from the Gulf of Mexico (DSDP Site 3) and was subsequently recorded in Lower Pliocene sediments (c. $4 \mathrm{Ma}$ in age) (Müller, 1974; Pujos, 1985). On the basis of the documented stratigraphic and geographical occurrences, C. mexicanus is considered a species with uncertain evolutionary development (Peleo-Alampay et al., 1998) despite its morphological similarity to the other Catinaster species. C. mexicanus has 'a very limited geographic distribution and seems to prefer specific environments. It usually occurs in the late Miocene' (Peleo-Alampay et al., 1998, p. 82). Similar occurrences of $C$. mexicanus in Miocene and Pliocene intervals were observed in sediment cores from IODP Site U1338. This study is intended to document in detail the recurrent presence of C. mexicanus in the stratigraphic record and investigate its possible evolutionary relationship with the other Catinaster species and/or with coeval Discoaster species.

\section{MATERIAL AND METHODS}

The intervals in the IODP Site U1338 sedimentary succession selected for this study correspond to the occurrences of $C$. mexicanus that were observed during on-board biostratigraphic analysis (IODP Expedition 320/321, Pälike et al., 2010) and, subsequently, in the more detailed study of the succession (M. Ciummelli, unpublished PhD thesis; Backman et al., 2013. For these studies, the complete Middle Miocene to Lower Pliocene section of Site U1338 was analysed and C. mexicanus specimens were observed in two short discrete intervals. The studied sediments are characterized by calcareous nannofossil ooze with varying concentrations of biosiliceous components, mostly diatoms, showing decimetric to metric lithological cycles. Across the two intervals with $C$. mexicanus, other samples were collected to improve sampling resolution. The average sampling resolution throughout the studied section (1 sample every $75 \mathrm{~cm})$ was improved to 1 sample every $10 \mathrm{~cm}$ in selected portions (from

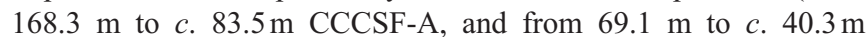
CCCSF-A depth intervals). Following standard procedures, 180 smear slides were made from unprocessed sediment and analysed using a Zeiss Axioscope at $1250 \times$. Semi-quantitative abundance evaluation of Catinaster species was obtained by counting the number of specimens in a prefixed area (Backman \& Shackleton, 1983). The same methodology was used to evaluate the abundance of Discoaster berggrenii Bukry, 1971 and Discoaster altus (Müller, 1974) in the Upper Miocene and Lower Pliocene sections, respectively.

A comparative analysis was performed at ODP Site 926 (Ceara Rise, Western Equatorial Atlantic; Curry et al., 1995) in 


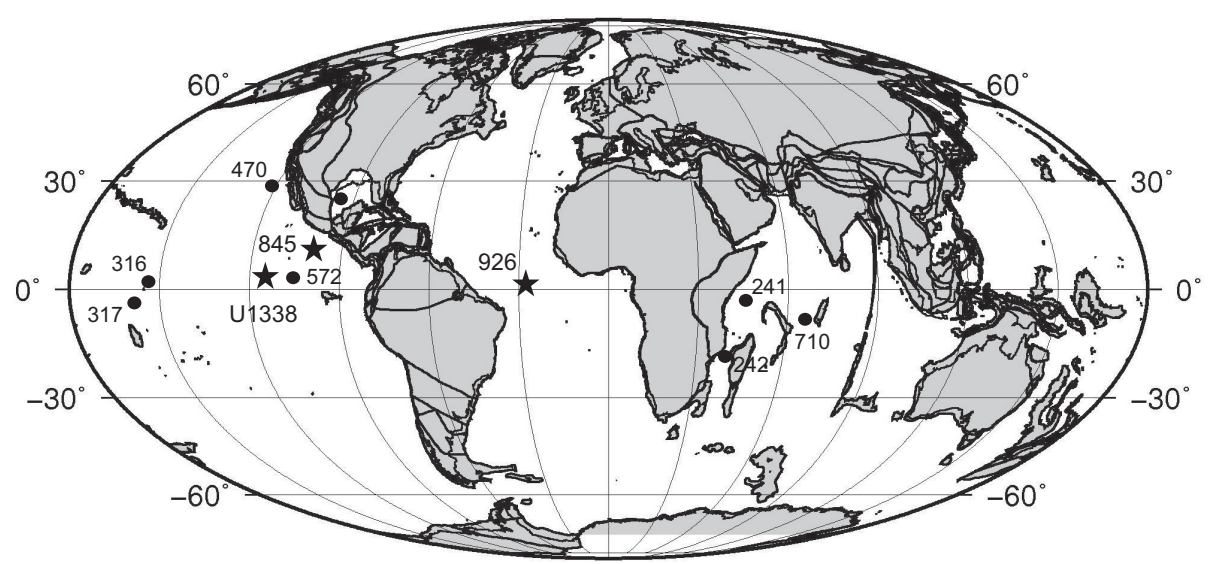

Fig. 1. Location of IODP/ODP sites (black stars) and DSDP/ODP sites (black circles) cited in the text on a palaeogeographical map at 4 Ma (modified from http://www.odsn.de/odsn/services/paleomap/paleomap.html).

which the same counting method was used in the same stratigraphic intervals as at Site U1338. Fifty-six samples from the Upper Miocene $(214.47-198.33 \mathrm{mcd})$ and 143 samples from the Lower Pliocene $(140.2-111.95 \mathrm{mcd})$ were analysed, taken from the set of samples used in a previous study on Miocene calcareous nannofossil biochronology (Backman \& Raffi, 1997). The range of $C$. mexicanus in the Upper Miocene was reconstructed also at ODP Site 845 , in 13 samples from c. $6 \mathrm{~m}$ of sediments of Hole 845A (core 12H, 108.7-103.2 $\mathrm{m}$ below sea floor (mbsf)).

All studied material is deposited in the Dipartimento di Ingegneria e Geologia (Ingeo) - CeRSGeo, Università 'G. d'Annunzio' di Chieti-Pescara.

\section{TAXONOMIC AND STRATIGRAPHIC REMARKS}

The characteristic morphology of Catinaster nannofossils is a basket-like shape with a variable outline in plan view, ranging from smooth sub-circular to hexagonal and/or denticulate forms (Plate 1). In this study, we considered the three described species of the genus, C. coalitus, C. calyculus and C. mexicanus. For simplicity, we did not adopt the taxonomic concepts proposed by PeleoAlampay et al. (1998) to differentiate subspecies within C. coalitus and C. calyculus.

C. coalitus is the first Catinaster species that appears in the stratigraphic record, at $10.79 \mathrm{Ma}$ (Backman et al., 2012), and it is used as biostratigraphic marker for defining Zone CNM12 ' $C$. coalitus BZ' of Backman et al. (2012) (equivalent to Zone CN6 of Okada \& Bukry, 1980, and Zone NN8 of Martini, 1971). C. coalitus evolved from the small Discoaster micros Theodoridis, 1984 (= Discoaster transitus Peleo-Alampay et al., 1998; Raffi et al., 1998), by reduction of the rays and expansion of the bifurcations that merge at the tips to form a basket.

Just above and after the first occurrence of $C$. coalitus, $C$. calyculus evolved from it through a gradual extension of the thin rays beyond the external central area profile (Peleo-Alampay et al., 1998; Raffi et al., 1998). The range of C. calyculus encompasses Zones CNM12 and CNM13 of Backman et al. (2012) (equivalent to Zones CN6 and CN7 of Okada \& Bukry, 1980, and NN8 and NN9 of Martini, 1971). Both C. coalitus and C. calyculus become extinct close to the top of Zone CNM13.
C. mexicanus was described by Bukry (1971) from Upper Miocene sediments from the Gulf of Mexico (DSDP Site 3) and also recorded in that site by Ellis et al. (1972). It was also observed in this time interval from sediment cores in the Eastern Pacific Ocean (DSDP Site 470; Bukry, 1981), the northern Gulf of Mexico (Jiang \& Watkins, 1992), and in two Eureka drill sites (E68-136 and E66-73) in the same area (Aubry, 1993), in the Eastern Equatorial Pacific Ocean (ODP Site 845; Peleo-Alampay et al., 1998) and in the Indian Ocean (ODP Site 710; PeleoAlampay et al., 1998). These reported scattered occurrences within nannofossil assemblages of zones CN7-CN9a of Okada \& Bukry (1980) indicate that C. mexicanus evolved later than the other Catinaster species. In addition, C. mexicanus was found in Lower Pliocene sediments from the Western Indian Ocean (DSDP Site 241; Müller, 1974) and the Equatorial Pacific (DSDP Sites 572 and 574; Pujos, 1985). However, this Pliocene occurrence, within Zones CN10 and CN11 of Okada \& Bukry (1980) has been considered doubtful (Pujos, 1985; Peleo-Alampay et al., 1998; see discussion below).

Discoaster altus was described by Müller (1974) from Pliocene sediments from the Western Indian Ocean (DSDP Site 242) within Zone CN11 of Okada \& Bukry (1980). From the same sediment cores Bukry (1976) described the species D. tristellifer that he observed also in the equatorial Pacific (DSDP Sites 316 and 317). Although Bukry (1976) provided a more detailed documentation for D. tristellifer based on light microscopy, and retained the two species separated, D. tristellifer is commonly considered a synonym of $D$. altus (see Young, 1998) and we follow this taxonomic concept.

\section{RESULTS}

The studied interval at IODP Site U1338 comprises the Upper Miocene-Lower Pliocene zones CNM12 through CNPL4 of Backman et al.'s (2012) zonation, corresponding to the time interval from c. $11 \mathrm{Ma}$ to $3.2 \mathrm{Ma}$ (Fig. 2). The biostratigraphic framework and chronology for Site U1338, and the data on the distribution of $C$. coalitus and C. calyculus (Fig. 2) are from Backman et al. (2013).

In the Upper Miocene, C. coalitus, C. calyculus and C. mexicanus show low abundances and fluctuating distribution patterns 


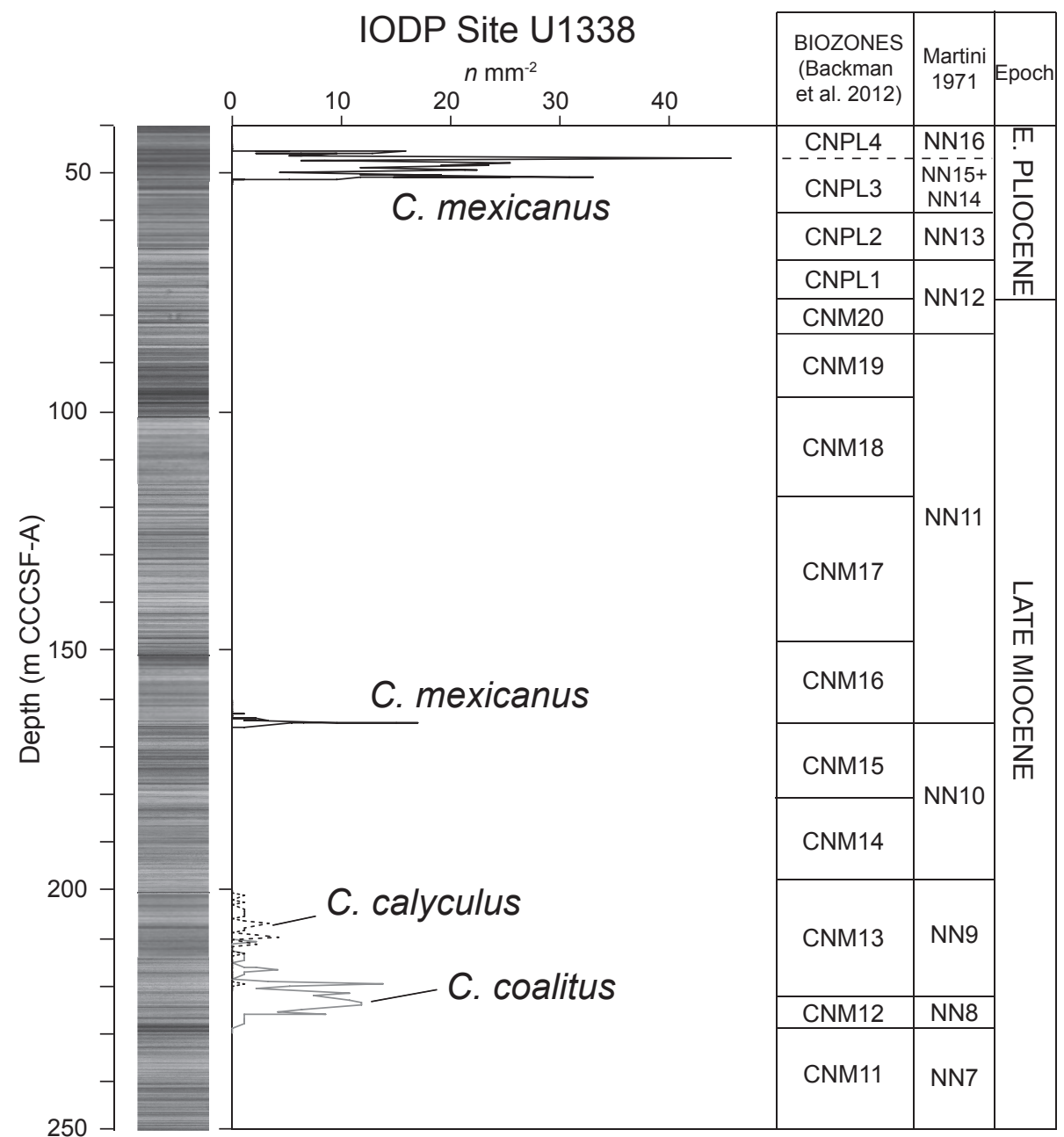

Fig. 2. Quantitative distribution ranges of Catinaster species and biostratigraphy (Backman et al. 2012; Martini, 1971), Upper Miocene-lower Pliocene interval, IODP Site U1338.

(Fig. 2). Specifically, C. coalitus and C. calyculus occur in the lower part of the Upper Miocene (228.46-201.37m CCCSF-A) within zones CNM12 and CNM13, conformably with their known world-wide stratigraphic distribution. C. calyculus occurs shortly after $C$. coalitus and specimens with intermediate morphological features between the two species are present (Pl. 1, fig. 4).

The distribution range of $C$. mexicanus is restricted to a $1.4 \mathrm{~m}$ thick sediment interval (165.13-164.21 m CCCSF-A; Fig. 2) in the mid-upper Miocene around $8 \mathrm{Ma}$. This C. mexicanus occurrence corresponds to a short time interval (c. $0.05 \mathrm{Ma})$ in the lower part of Zone CNM16 (equivalent to Zone CN9a of Okada \& Bukry, 1980, and lower part of Zone NN11 of Martini, 1971). The short range is clearly disjunct from the C. coalitus-C. calyculus evolutionary sequence and is concomitant with the appearance of Discoaster berggrenii (Fig. 3). The same distribution for $C$. mexicanus, co-occurring with $D$. berggrenii, is observed in Upper Miocene sediments at Site 845 (Fig. 4), located in the Eastern Equatorial Pacific as Site U1338.

In the other succession considered in this study, ODP Site 926 (Curry et al., 1995), previous biostratigraphic and biochronological analysis on a high resolution sampling set (Backman \& Raffi,
1997) did not provide evidence of the presence of C. mexicanus. Nevertheless, we selected specific intervals to search for C. mexicanus, in stratigraphic positions time-correlative to the occurrences at Site U1338. As a reference, we considered the biostratigraphy and biochronology of Site 926 (Curry et al., 1995; Shackleton \& Crowhurst, 1997; Backman \& Raffi, 1997). C. mexicanus was extremely rare in scattered samples, often as a single specimen, in a short interval of the Upper Miocene (208.425$210.66 \mathrm{mcd}$; Fig. 5) that corresponds to a time interval of c. 0.05 $\mathrm{Ma}$, according to the chronology of Site 926 (Shackleton \& Crowhurst, 1997).

In the Lower Pliocene section of Site U1338, C. mexicanus and $D$. altus have consecutive distribution ranges within a stratigraphic interval of c. $30 \mathrm{~m}$ that corresponds to a time interval of about $0.4 \mathrm{Ma}$. The two species are continuously present and show variable but significant abundances within their ranges (Fig. 6). A clear abundance turnover occurs at $51.35 \mathrm{~m} \mathrm{CCCSF-A,} \mathrm{with} C$. mexicanus sharply increasing in abundance when $D$. altus declines toward its disappearance. D. altus specimens with very short rays are common just below the Pliocene appearance of $C$. mexicanus (Fig. 6) and bear some resemblance to C. mexicanus specimens. 


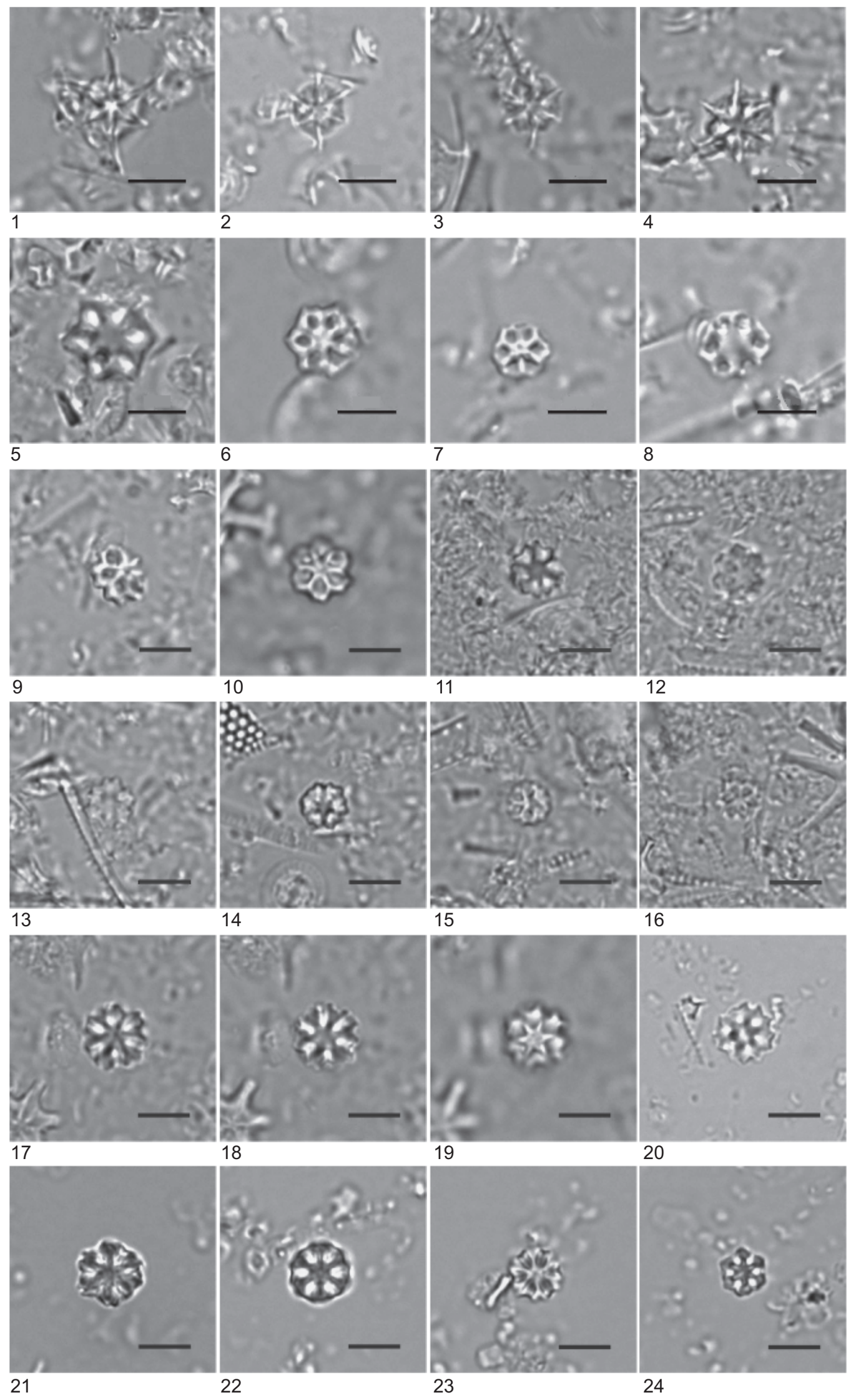


A Lower Pliocene occurrence of C. mexicanus was also found in samples from ODP Site 926 in a short interval from 129.86 med to $117.18 \mathrm{mcd}$ (Fig. 5). The species has a scattered distribution and is extremely rare, showing the same pattern that was observed in the Upper Miocene. At this location only a few specimens of $D$. altus were found concomitantly with $C$. mexicanus. Although quantitatively irrelevant in comparison with the occurrences in the Pacific sites, the presence of $C$. mexicanus at Site 926 is significant because it provides evidence for a wider geographical distribution for the species and confirms its Pliocene occurrence.

\section{DISCUSSION}

The data obtained from the study of Site U1338 confirm that the origin of $C$. mexicanus is independent from the other catinasters, as inferred by Peleo-Alampay et al. (1998) on the basis of morphological observations. Those authors suggested that $C$. mexicanus could be a second derivation from Discoaster, but stratophentic evidence of a specific Discoaster species as a possible ancestor was never found. In the Discoaster assemblage coeval with the Upper Miocene occurrence of $C$. mexicanus there are no species that could be morphologically related to it and so could be considered the ancestor taxon, as D. micros/D. transitus was the ancestor of the first Catinaster species $C$. coalitus $c$. 2.8 Ma earlier. The alternative hypothesis that $C$. mexicanus could be a 'preservational fragment of a discoaster rather than a genuine species' (J. Young in Peleo-Alampay et al., 1998, p. 77) is in conflict with the data presented here. Although C. mexicanus occurs in association with $D$. berggrenii, there is no morphological evidence indicating that $C$. mexicanus specimens could result from dissolution of $D$. berggrenii specimens, namely through corrosion of the rays. The star-shaped knob in the central area of $D$. berggrenii, with pentaradiate symmetry, differs in morphology and size from the hexaradiate symmetry of Miocene specimens of $C$. mexicanus (Fig. 3). This morphological difference is even more striking in the specimens observed at ODP Site 845 (Fig. 4) whose morphology would suggest the presence of an ancestral taxon similar to D. micros that, however, is not found in the assemblage.

The effect of preservation as responsible for 'origination' of $C$. mexicanus has been previously postulated by Pujos (1985) to explain the common but anomalous presence, in Pliocene sediments at DSDP Site 572, of Catinaster specimens, considered then as a typically, maybe exclusively, Miocene taxon. The author regarded the Pliocene $C$. mexicanus specimens as 'relicts' of dissolved specimens of $D$. tristellifer (syn. of D. altus) on the basis of the morphological affinity between $C$. mexicanus and the stellate (hexaradiate) knob in the central area of $D$. altus. On the other hand, Perch-Nielsen (pers. comm., in Aubry, 1984) suggested that $D$. altus could be considered an evolutionary link between Discoaster and Catinaster.
From analysis of Lower Pliocene sediments at Site U1338, it is clear that the possible 'preservational origin' for $C$. mexicanus is contradicted by the lack of signs of etching on the rest of the nannofossil assemblage. Therefore, it seems unlikely that the presence of C. mexicanus represents an 'artefact' of dissolution of D. altus specimens. Instead, it is an evolutionary appearance, and D. altus is representative of the evolutionary link between Discoaster and Catinaster in the Pliocene, in agreement with Perch-Nielsen's suggestion. The $C$. mexicanus specimens observed in the Upper Miocene are identical to the Lower Pliocene specimens (Plate 1, cf. figs 11 and 20), show the same morphological variability (except for a slightly larger average size in the Pliocene specimens) but do not seem morphologically related to any preceding or coeval Discoaster species. These data suggest that $C$. mexicanus could be an unrelated homeomorph of the catinasters that evolved from Discoaster at least twice in the Late Miocene and in the Early Pliocene, in agreement with the hypothesis of Young (in Peleo-Alampay et al., 1998, p. 77; and pers. comm.), although the late Miocene emergence is not supported by the presence of an ancestor species.

The morphological similarity between $C$. mexicanus and $D$. altus pertains to the whole structure of the catinaster and massive central area of the discoasterid, both having hexaradiate symmetry. A similar morphological affinity associates, in the early Late Miocene, the earlier catinasters $C$. coalitus and $C$. calyculus with the coeval Discoaster musicus Stradner, 1959 and D. sanmiguelensis Bukry, 1981, bearing a stellate (hexaradiate) knob in the central area. The Upper Miocene C. mexicanus occurrence is also concomitant with discoasterids bearing a prominent stellate ornamentation in the central area $(D$. berggrenii), although with lack of other similarity. Therefore, it is noteworthy that discoasterids (Catinaster and Discoaster) at times developed a common morphological feature, namely a prominent stellate structure, with or without hexaradiate symmetry. These records could be interpreted as episodes of iterative evolution, possibly controlled by the influence of recurrent changes in climatic/environmental conditions, such as those existing in the Eastern Equatorial Pacific in the late Miocene-early Pliocene (Pälike et al., 2010).

If future studies should confirm that $C$. mexicanus does not have any evolutionary relationship with the earlier catinasters, pointing to a polyphyletic character of the Catinaster lineage, then its taxonomy would need to be revised.

The presence of C. mexicanus at Site U1338 and Site 926 suggests a wider areal distribution for this species, that can be extended from 'semi-enclosed basins or in locations proximal to the continental borderland' (Peleo-Alampay et al., 1998, p. 82) to the warm waters in an open-ocean realm. The significant abundance of $C$. mexicanus at Site U1338 could indicate that high nutrient conditions, prevailing at that site (Pälike et al., 2010; Backman et al., 2013), could have favourably affected its productivity in contrast to its suppressed abundance in more oligotrophic settings, such as Site 926.

Explanation of Plate 1. figs 1-3. Catinaster calyculus: 1, sample U1338B-23H-2, 70-71 cm; 2, sample U1338B-24H-3, 142-143 cm; 3, sample U1338B-24H-4, 72-73 cm. fig. 4 Catinaster coalitus-Catinaster calyculus intermediate morphotype (sample U1338A-24H-4, 58-59 cm). figs 5-7. Catinaster coalitus: 5, sample U1338B-24H-5, 142-143 cm; 6, sample U1338B-24H-6, 72-73 cm; 7, sample U1338B-24H-4, 142-143 cm. fig. 8. Discoaster micros-Catinaster coalitus intermediate morphotype (sample U1338A-25H-4, 120-121 cm). figs 9-16. Upper Miocene Catinaster mexicanus: 9, 13, samples U1338B-18H-4, 50-51 cm; 10, 14, 15, 16, sample U1338B-18H-4, 60-61 cm; 11, 12, sample U1338B-18H-4, 70-71 cm. figs 17-24. Lower Pliocene Catinaster mexicanus: 17, 19, same specimen at different focus (sample U1338B-6H-5, 5-6cm); 18, 20, sample U1338B-6H-5, 5-6cm); 21, sample U1338B-6H-4, 45-46 cm; 22, 23, 24, sample U1338B-6H-4, 120-121 cm. Magnification 1250×. Scale bars $5 \mu \mathrm{m}$. 
IODP Site U1338

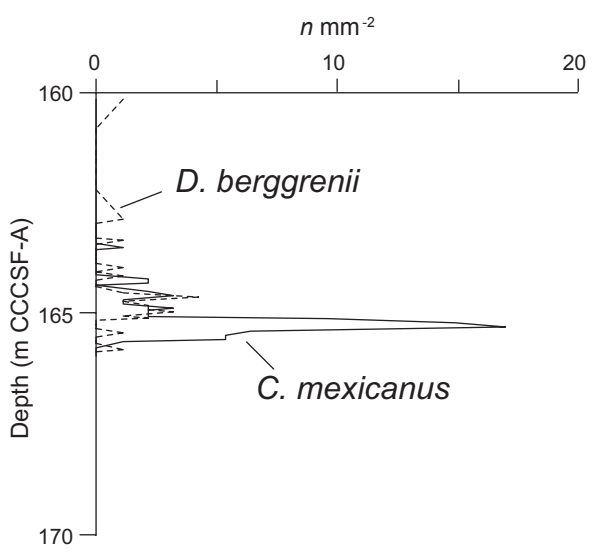

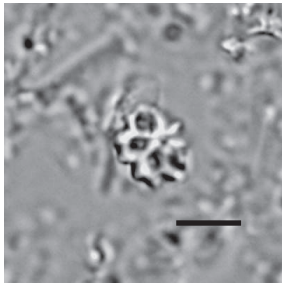

1

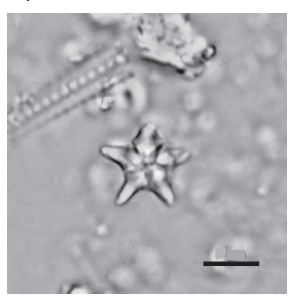

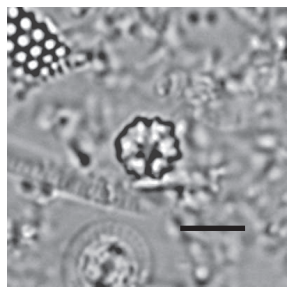

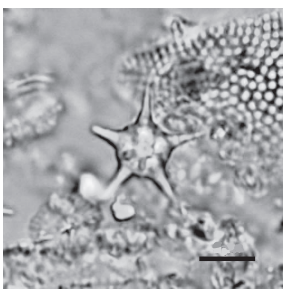

4

Fig. 3. Abundance of Catinaster mexicanus and Discoaster berggrenii in the Upper Miocene at IODP Site U1338. 1, 2. Catinaster mexicanus: 1, sample U1338B-18H-4, 50-51 cm; 2, sample U1338B-18H-4, 60-61 cm. 3, 4. Discoaster berggrenii: 3, sample U1338B-13H-2, 120-121 cm; 4, sample U1338B-13H-3, 45-46 cm. Magnification 1250×. Scale bars $5 \mu \mathrm{m}$.

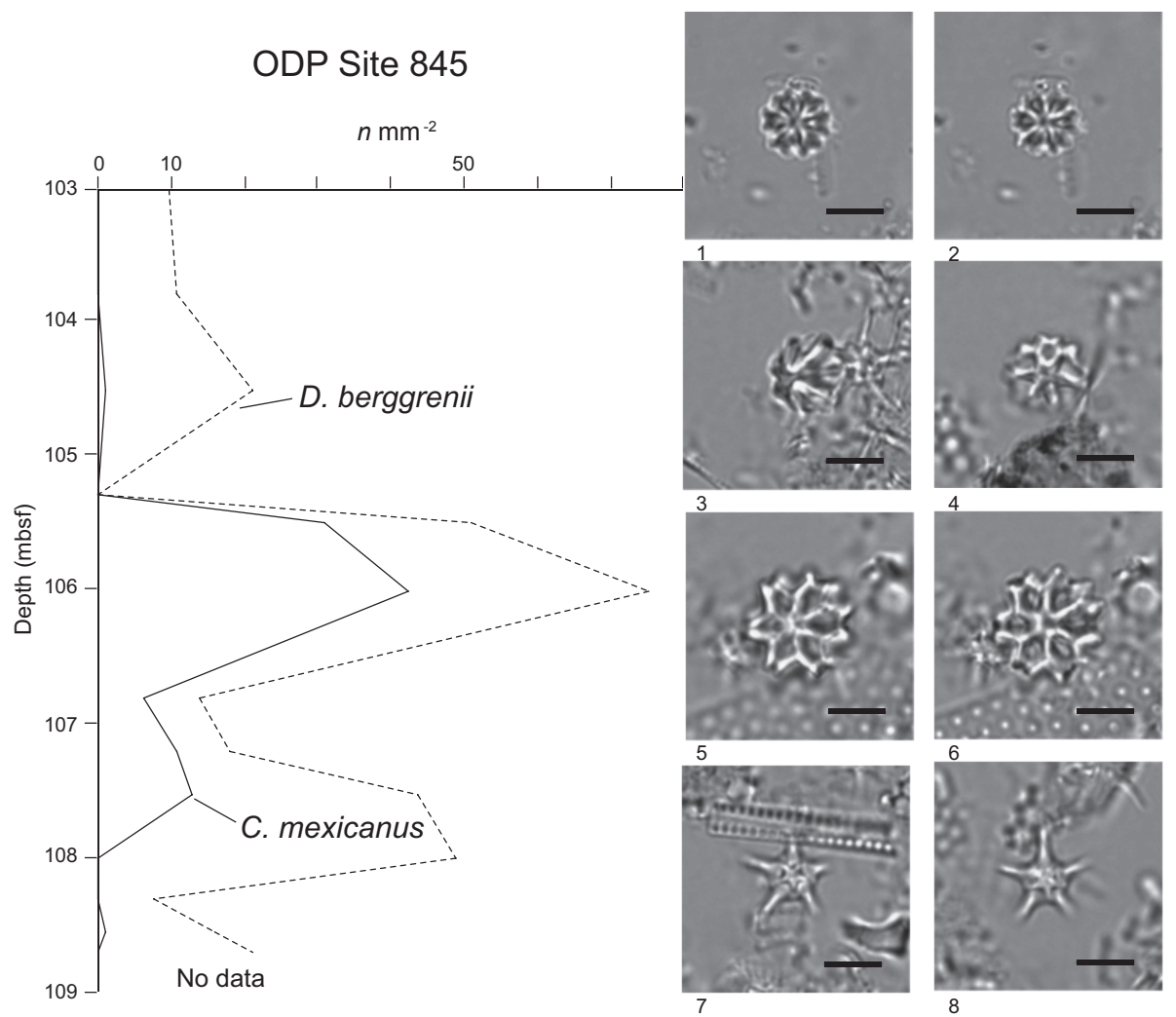

Fig. 4. Abundance of Catinaster mexicanus and Discoaster berggrenii in the Upper Miocene at ODP Site 845. 1-6. Catinaster mexicanus: 1, 2, same specimen at different focus (sample 845A-12H-2, 141-142 cm); 3, 4, sample 845A-12H-3, 42-43 cm; 5, 6, same specimen at different focus (sample 845A-12H-3, 42-43 cm). 7, 8. Discoaster berggrenii (sample 845A-12H-3, 42-43 cm). Magnification 1250×. Scale bars $5 \mu \mathrm{m}$.

\section{SYSTEMATIC PALAEONTOLOGY}

Family Discoasteraceae Tan, 1927

Genus Catinaster Martini \& Bramlette, 1963

Catinaster mexicanus Bukry, 1971

(P1. 1, figs 9-24)

1971 Catinaster mexicanus Bukry: p. 50, pl. 3, 7-9.

1972 Catinaster mexicanus Bukry; Ellis et al.: p. 37, pl. 10, fig. 1.
Description. Catinaster mexicanus is a small and thick nannolith with six short and bifurcated rays that merge at the tips creating a broadly circular and crenate margin with hexaradiate symmetry. A star-shaped knob is present in the centre.

Occurrence. C. mexicanus is present in Upper Miocene zones CN8-CN9 (of Okada \& Bukry, 1980) and NN10-NN11 (of Martini, 1971) at DSDP Site 3 (Gulf of Mexico; Bukry, 1971; Ellis et al., 


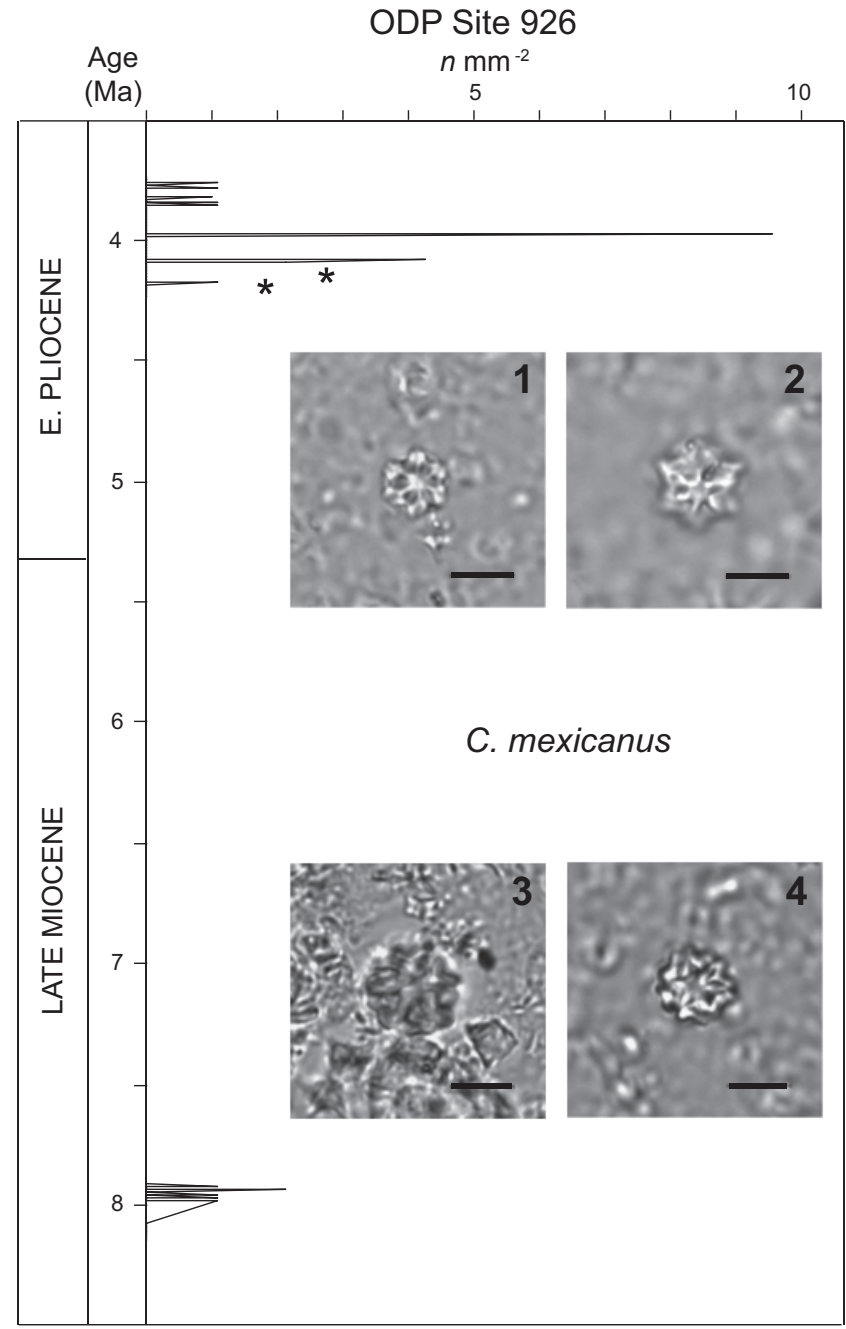

Fig. 5. Abundance of Catinaster mexicanus in the Upper Miocene-Lower Pliocene interval at ODP Site 926. Chronology from Shackleton \& Crowhurst (1997) and Backman \& Raffi (1997). 1, 2. Catinaster mexicanus (Lower Pliocene) (sample 926C-12H-5, 7-9 cm). 3, 4. Catinaster mexicanus (Upper Miocene) (sample 926B-20H-6, 64-65 cm). Asterisks indicate the presence of Discoaster altus. Magnification 1250×. Scale bars $5 \mu \mathrm{m}$.

1972), at DSDP Site 470, ODP Site 845 and IODP Site U1338 (Eastern Pacific Ocean; Bukry, 1981; Peleo-Alampay et al., 1998; this study), at ODP Site 710 (Indian Ocean; Peleo-Alampay et al., 1998), at ODP Site 926 (Equatorial Atlantic Ocean; this study), and in the northern Gulf of Mexico (Jiang and Watkins, 1992; Aubry, 1993). In the Lower Pliocene, C. mexicanus is present in sediments of zones CN 11 (of Okada \& Bukry, 1980) and NN15 (of Martini, 1971) at DSDP Site 241 (Western Indian Ocean; Müller, 1974), and at DSDP Sites 572 and 574 (Equatorial Pacific Ocean; Pujos, 1985). It is present in the interval between subzones CN11b to lower CN12a (NN15-lower NN16) at IODP Site U1338 (Eastern Equatorial Pacific Ocean) and ODP Site 926 (Equatorial Atlantic) (this study), corresponding to the interval uppermost Zone CNPL3lowermost Zone CNPL4 (of Backman et al., 2012).

Remarks. C. mexicanus is similar to $C$. coalitus (P1. 1, cf. figs 6-7 with figs 10-11), has a somewhat more elaborate external profile, derived from the merging of six short and bifurcated rays, and a star-shaped structure in the central area that is evident through a light microscope focal series. C. mexicanus is similar to $D$. altus specimens with very short rays. The central area of $D$. altus differs from $C$. mexicanus in having a large star-shaped knob on the proximal side and a smaller one on the distal side.

Family Discoasteraceae Tan, 1927

Genus Discoaster Tan, 1927

Discoaster altus Müller, 1974

1974 Discoaster altus Müller: p. 592, pl. 9, figs 1-3. 1976 Discoaster tristellifer Bukry: p. 499, pl.1, figs 1-17.

Description. A valid description of $D$. altus was made by Bukry (1976, p. 499), describing the species Discoaster tristellifer, considered to be a junior synonym by Young (1998),

(D. tristellifer) is typically six rayed and is characterized by star-shaped knobs of different diameter on opposite sides of the central area. The main rays are long and taper from simple points or slightly indented tips toward the central area. The larger of the two central knobs fills most of the central area and has its six points aligned with the discoaster rays. The smaller knob, projecting from the center of the discoaster on the opposite side, has its points aligned between the discoaster rays.

Occurrence. D. altus was observed in Lower Pliocene sediments within Zone CN11 (of Okada \& Bukry, 1980) and NN13 (of Martini, 1971) at DSDP Site 242 (Western Indian Ocean; Müller, 1974; Bukry, 1976), at DSDP Sites 316 and 317 and IODP Site U1338 (Equatorial Pacific Ocean; Bukry, 1976; this study) and at ODP Site 926 (Atlantic Ocean; this study).

Remarks. Specimens with very short rays show morphological similarities with specimens of the genus Catinaster, specifically Catinaster mexicanus (Fig. 6).

\section{CONCLUSIONS}

The documented stratigraphic occurrence of $C$. mexicanus in specific time intervals indicates that its evolutionary relationship with other discoasterids (other species of genera Catinaster and Discoaster) is not straightforward. C. mexicanus entered the stratigraphic record in the Late Miocene and occurred for a short time interval of $c$. $50 \mathrm{ka}$, with scarce but typical specimens. This finding confirms the absence of an evolutionary relationship of C. mexicanus with the earlier $C$. coalitus and $C$. calyculus species, and indicates that $C$. mexicanus could have had an independent origin as a second derivation from Discoaster, despite the absence of a recognizable ancestor species at present. The second $C$. mexicanus occurrence, after $c$. $4 \mathrm{Ma}$ in the early Pliocene, is linked to the extinction of $D$. altus. The two species share morphological similarity, evident in the thick hexaradiate structure of the catinaster and the thick stellate central area of the discoaster. Also, the Upper Miocene specimens of C. mexicanus co-occur with discoasters bearing a prominent star-shaped knob in the central area (D. berggrenii), but the two species lack other morphological similarity. These data suggest that discoasterids (Catinaster and Discoaster) at times developed a common morphological feature, the prominent star-shaped structure, and 

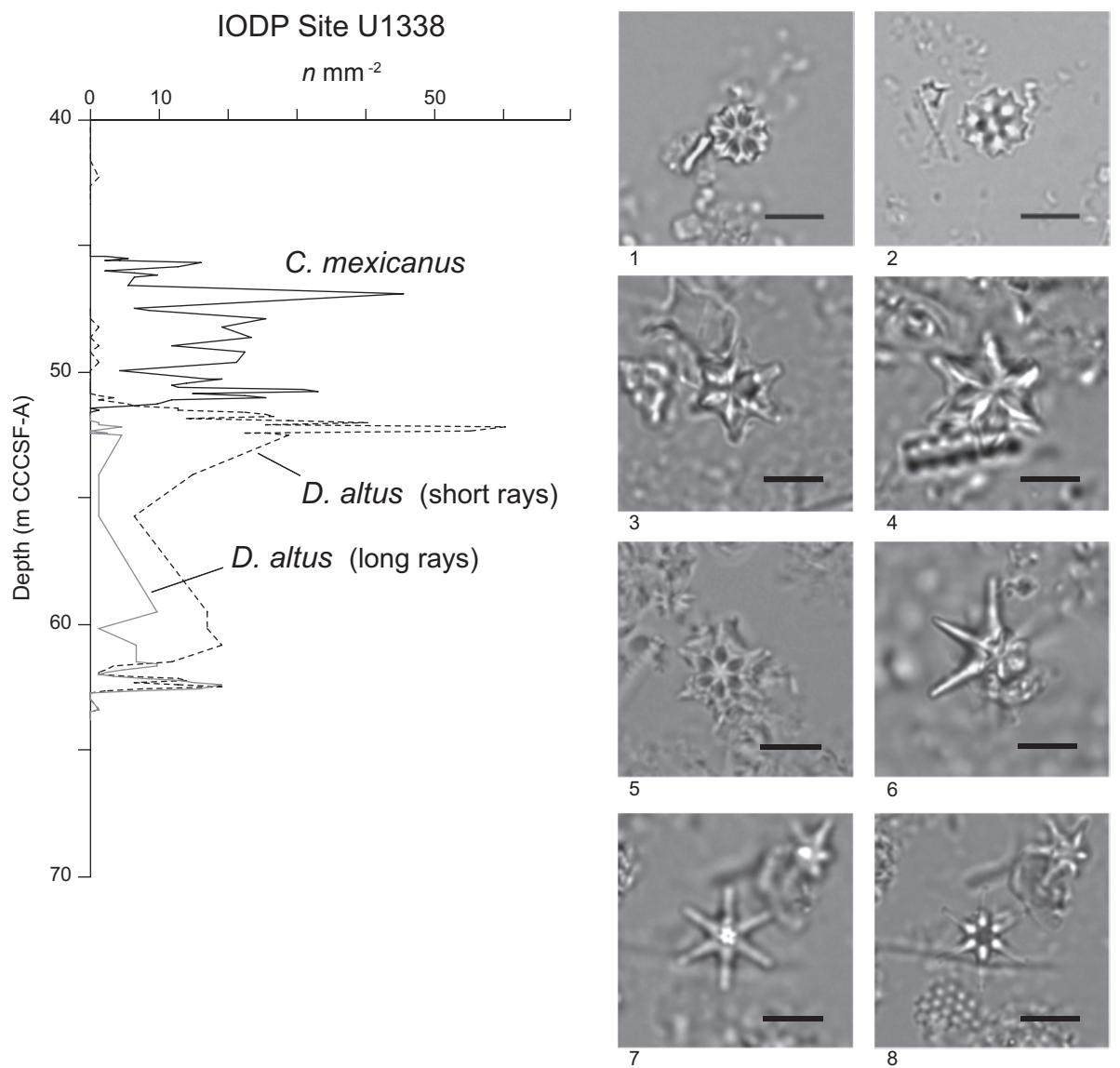

Fig. 6. Abundance of Catinaster mexicanus and Discoaster altus in the Lower Pliocene at IODP Site U1338. 1, 2. Catinaster mexicanus: 1, sample U1338B-6H-4, 120-121 cm; 2, sample U1338B-6H-5, 5-6 cm. 3-5. Discoaster altus with short rays: 3, sample U1338B-6H-5, 110-111 cm; 4, sample U1338B-6H-5, 90-91 cm; 5, sample U1338A-7H-6, 120-121 cm. 6-8. Discoaster altus with long rays: 6, sample U1338B-7H-5, 45-46 cm; 7, 8, same specimen at different focal levels (sample U1338B-7H-6, 70-71 cm). Magnification x1250. Scale bar $5 \mu \mathrm{m}$.

this resulted in the repeated occurrence of similar taxa. These occurrences could be interpreted as episodes of iterative evolution within Discoasteraceae and the recurring taxa would need taxonomic revision, when and if further studies confirm this evolutionary pattern.

The low abundance of $C$. mexicanus at Site 926, in comparison with its common occurrence at Sites U1338 and 845, could be explained by the different environmental conditions between the two oceanic areas, namely the oligotrophic waters of the Equatorial Atlantic (Site 926) and the high nutrient conditions in the Eastern Equatorial Pacific (Sites U1338 and 845).

\section{ACKNOWLEDGEMENTS}

We are grateful to Jan Backman for constructive discussions on taxonomy, and to Jeremy Young and an anonymous reviewer for helpful suggestions in the review of the manuscript. This work was carried out with financial support from Università 'G. d'Annunzio' Chieti-Pescara. Samples were provided by the Integrated Ocean Drilling Program (IODP) and Ocean Drilling Program (ODP).

\section{Manuscript received 24 January 2013 \\ Manuscript accepted 25 April 2013}

Scientific Editing by Jeremy Young

\section{REFERENCES}

Aubry, M.-P. 1984. Handbook of Cenozoic Calcareous Nannoplankton (Book 1): Ortholithae (Discoasters). Micropaleontology Press, New York, 266pp.

Aubry, M.-P. 1993. Neogene allostratigraphy and depositional history of the De Soto Canyon area, northern Gulf of Mexico. Micropaleontology, 39: 327-366.

Backman, J. \& Raffi, I. 1997. Calibration of Miocene nannofossil events to orbitally tuned cyclostratigraphies from Ceara Rise. In Shackleton, N.J., Curry, W.B., Richter, C. \& Bralower, T.J., Proceedings of the Ocean Drilling Program, Scientific Results, 154: 83-99. http://dx.doi. org/10.2973/odp.proc.sr.154.101.1997

Backman, J. \& Shackleton, N.J. 1983. Quantitative biochronology of Pliocene and early Pleistocene calcareous nannofossils from the Atlantic, Indian and Pacific oceans. Marine Micropaleontology, 8: 141170. http://dx.doi.org/10.1016/0377-8398(83)90009-9

Backman, J., Raffi, I., Rio, D., Fornaciari, E. \& Pälike, H. 2012. Biozonation and biochronology of Miocene through Pleistocene calcareous nannofossils from low and middle latitudes. Newsletters on Stratigraphy, 45: 221-244.

Backman, J., Raffi, I., Ciummelli, M. \& Baldauf, J. 2013. Species-specific responses of late Miocene Discoaster spp. to enhanced biosilica productivity conditions in the equitorial Pacific and the Mediterranean. GeoMarine Letters, http://dx.doi.org/10.1007/500367-013-0328-0.

Bukry, D. 1971. Discoaster evolutionary trends. Micropaleontology, 17: $43-52$. 
Bukry, D. 1973. Coccolith stratigraphy, eastern equatorial Pacific, Leg 16, Deep Sea Drilling Project. In Van Andel, T.H. \& Heath, G.R. Initial Reports of the Deep Sea Drilling Project, 16: 653-711. http://dx.doi. org/10.2973/dsdp.proc.16.126.1973.

Bukry, D. 1976. Coccolith stratigraphy of Manihiki Plateau, Central Pacific, Deep Sea Drilling Project, Site 317. In Schlanger, S.O., Jackson, E.D. et al., Initial Reports of the Deep Sea Drilling Project, 33: 493-501.

Bukry, D. 1981. Pacific coast coccolith stratigraphy between Point Conception and Cabo Corrientes, Deep Sea Drilling Project Leg 63. In Yeats, R.S., Haq, B.U. et al., Initial Reports of the Deep Sea Drilling Project, 63: 445-471. http://dx.doi.org/10.2973/dsdp. proc.63.111.1981.

Curry, W.B., Shackleton, N.J., Richter, C. et al. 1995. Proceedings of the Ocean Drilling Program, Initial Reports, 154: 153-232. http://dx.doi. org/10.2973/odp.proc.ir.154.1995.

Ellis, C.H., Lohmann, W.H. \& Wray, J.L. 1972. Upper Cenozoic calcareous nannofossils from the Gulf of Mexico (Deep Sea Drilling Project, Leg 1, Site 3). Colorado School of Mines Quarterly, 67: 1-103.

Jiang, M.M. \& Watkins, J.S. 1992. Floral pulses, foraminiferal peaks and inferred sequences in the Miocene of the northern Gulf of Mexico. Marine and Petroleum Geology, 9: 608-622. http://dx.doi. org/10.1016/0264-8172(92)90034-C

Martini, E. 1971. Standard Tertiary and Quaternary calcareous nannoplankton zonation. In Farinacci, A. (Ed.), Proceedings of the II Planktonic Conference, Roma, 1970, 739-785.

Martini, E. \& Bramlette, M.N. 1963. Calcareous nannoplankton from the experimental Mohole drilling. Journal of Paleontology, 37: 845-855.

Müller, C. 1974. Calcareous nannoplankton, Leg 25 (western Indian Ocean). In Simpson, E.S.W., Schlich, R. et al., Initial Reports of the
Deep Sea Drilling Project, 25: 579-633. http://dx.doi.org/10.2973/dsdp. proc.25.126.1974

Okada, H. \& Bukry, D. 1980. Supplementary modification and introduction of code numbers to the low-latitude coccolith biostratigraphic zonation (Bukry, 1973; 1975). Marine Micropaleontology, 5: 321-325. http://dx.doi.org/10.1016/0377-8398(80)90016-X

Pälike, H., Lyle, M., Nishi, H. et al. 2010. Pacific equatorial age transect. Proceedings of the Integrated Ocean Drilling Program, 320/321: 1-141. http://dx.doi.org/10.2204/iodp.proc.320321.101.2010.

Peleo-Alampay, A., Bukry, D., Liu, L. \& Young, J.R. 1998. Late Miocene calcareous nannofossil genus Catinaster: taxonomy, evolution and magnetobiochronology. Journal of Micropalaeontology, 17, 71-85. http:// dx.doi.org/10.1144/jm.17.1.71

Pujos, A. 1985. Cenozoic nannofossils, central equatorial Pacific, Deep Sea Drilling Project Leg 85. In Mayer, L., Theyer, F., Thomas, E. et al., Initial Reports of the Deep Sea Drilling Project, 85: 581-607. http://dx.doi.org/10.2973/dsdp.proc.85.114.1985

Raffi, I., Backman, J. \& Rio, D. 1998. Evolutionary trends of tropical calcareous nannofossils in the late Neogene. Marine Micropaleontology, 35: 17-41. http://dx.doi.org/10.1016/S0377-8398(98)00014-0.

Shackleton, N.J. \& Crowhurst, S. 1997. Sediment fluxes based on an orbitally tuned time scale $5 \mathrm{Ma}$ to $14 \mathrm{Ma}$, Site 926. In Shackleton, N.J., Curry, W.B., Richter, C. \& Bralower, T.J., Proceedings of the Ocean Drilling Program, Scientific Results, 154: 69-82. http://dx.doi. org/10.2973/odp.proc.sr.154.102.1997

Tan, S.H. 1927. Discoasteridae incertae sedis. Proceedings of the Koninklijke Nederlandse Akademie van Wetenschappen, 30: 411-419.

Young, J.R. 1998. Neogene. In Bown, P.R. (Ed.), Calcareous Nannofossil Biostratigraphy. Kluwer Academic Publishers, London, 225-265. 